DOI: 10.18276/sip.2016.45/1-29

\title{
Henryk Kowgier*
}

Uniwersytet Szczeciński

\section{PORÓWNANIE DYNAMIKI PRODUKCJI W BUDOWNICTWIE W POLSCE Z DYNAMIKA PRODUKCJI W BUDOWNICTWIE KRAJÓW UNII EUROPEJSKIEJ W LATACH 2006-2014}

\section{Streszczenie}

W artykule dokonano porównania dynamiki produkcji w budownictwie w Polsce z dynamiką produkcji w budownictwie wybranych krajów Unii Europejskiej w latach 20062014, wykorzystując do tego celu dane nieuwzględniające sezonowości, zaczerpnięte z GUS (2015). Zwrócono uwagę na to, że Polska miała w badanym okresie największą średnią dynamikę w Unii Europejskiej. Zbudowano również modele liniowe, które łączą dynamikę w Polsce z dynamiką niektórych krajów Unii. Artykuł kończą stosowne wnioski związane z przeprowadzoną analizą statystyczną.

Słowa kluczowe: analiza statystyczna, dynamika produkcji w budownictwie

\section{Wstęp}

Do badania zmian w czasie najczęściej wykorzystuje się wskaźniki dynamiki o podstawie stałej i o podstawie zmiennej. Punktami odniesienia są odpowiednio: okres bazowy lub okres poprzedzający. Porównując ze sobą dwa okresy, dzielimy dane dotyczące okresu badanego (zazwyczaj jest to bieżący rok) przez dane dotyczące okresu wyjściowego - zwyczajowo jest to rok przeszły. Wynik mnożymy

Adres e-mail: kowhenry@interia.eu. 
przez $100 \%$. Wskaźnik dynamiki informuje o tym, jak dane zjawisko uległo zmianie, czy na przykład stopa inflacji rośnie i jak szybko w porównaniu do roku poprzedniego, czy też jak szybko rośnie, czy maleje bezrobocie itp. Jak wynika z raportu przygotowanego przez globalną sieć przedsiębiorstw świadczących usługi księgowe, audytorskie i doradcze $(\mathrm{PwC})$ oraz Polski Związek Firm Deweloperskich (PZFD), rynek budowlany w Polsce to potężna i wciąż rozwijająca się gałąź gospodarki. Przykładowo wartość dodana wytworzona bezpośrednio przez sektor budowlany w roku 2014 wyniosła ponad 115 mld zł i stanowiła 6,7\% PKB. Sektor budowlany był i jest $\mathrm{w}$ dalszym ciągu ważnym płatnikiem podatków zasilających budżet państwa. Szacowane dochody z podatku VAT w roku 2014 wyniosły około 6,5-,07 mld zł, czyli około 2,7 p.p. dochodów podatkowych ogółem i około 5,6 p.p. całkowitych dochodów z podatku VAT w Polsce. Należy dodać, że działalność budowlana jest jednym z najistotniejszych kreatorów popytu dla innych sektorów gospodarki - od przemysłu, poprzez usługi i handel, jak również ma bardzo duże znaczenie dla wszystkich gospodarek regionalnych w Polsce. Celem artykułu jest porównanie dynamiki produkcji w budownictwie w Polsce z dynamiką produkcji w budownictwie w wybranych krajach Unii Europejskiej w latach 2006-2014. W badaniach wykorzystano dane zaczerpnięte z opracowań GUS, posługując się głównie metodę statystyczną w zakresie: analizy korelacji, regresji oraz analizy wybranych statystyk opisowych. W celu przeprowadzenia stosownych badań informacje o wskaźnikach dynamiki o podstawie zmiennej zaczerpnięte z GUS umieszczono w tabelach 1-2. Dotyczą one wskaźników dynamiki wszystkich działów związanych $\mathrm{z}$ budownictwem $\mathrm{w}$ danych krajach Unii Europejskiej.

Tabela 1. Dynamika produkcji w budownictwie w krajach Unii Europejskiej w latach 2006-2014

\begin{tabular}{|l|c|c|c|c|c|c|c|}
\hline Lata & P & WBR & N & F & H & PR & IR \\
\hline 1 & 2 & 3 & 4 & 5 & 6 & 7 & 8 \\
\hline 2006 & 115,9 & 101,4 & 106,1 & 102,5 & 102,2 & 93,9 & 103,9 \\
\hline 2007 & 116,5 & 102,3 & 102,8 & 104,3 & 95,7 & 96,0 & 86,5 \\
\hline 2008 & 110,0 & 98,7 & 99,8 & 98,0 & 83,7 & 95,8 & 70,8 \\
\hline 2009 & 104,6 & 88,4 & 99,9 & 94,6 & 88,8 & 90,1 & 63,1 \\
\hline 2010 & 104,6 & 107,2 & 99,5 & 97,6 & 79,6 & 89,1 & 70,3 \\
\hline 2011 & 111,8 & 102,2 & 107,8 & 98,3 & 80,3 & 87,3 & 83,3 \\
\hline 2012 & 93,7 & 92,4 & 99,0 & 94,7 & 94,6 & 83,8 & 97,6 \\
\hline 2013 & 94,1 & 101,6 & 99,7 & 100,4 & 101,4 & 84,1 & 111,4 \\
\hline
\end{tabular}




\begin{tabular}{|l|c|c|c|c|c|c|c|}
\hline 1 & 2 & 3 & 4 & 5 & 6 & 7 & 8 \\
\hline 2014 & 105,9 & 108,7 & 102,7 & 97,0 & 117,5 & 91,1 & 108,1 \\
\hline & FIN & CZ & SŁE & SŁO & LI & ŁO & W \\
\hline 2006 & 107,8 & 106,3 & 115,7 & 115,7 & 121,5 & 113,3 & 103,8 \\
\hline 2007 & 111,0 & 106,9 & 118,5 & 105,7 & 122,4 & 113,7 & 106,4 \\
\hline 2008 & 103,3 & 100,1 & 115,5 & 111,4 & 104,3 & 97,1 & 99,1 \\
\hline 2009 & 87,4 & 99,4 & 79,0 & 89,2 & 51,7 & 65,0 & 88,5 \\
\hline 2010 & 111,5 & 92,3 & 83,1 & 95,2 & 92,3 & 76,5 & 96,4 \\
\hline 2011 & 108,1 & 96,4 & 75,2 & 97,9 & 122,4 & 112,4 & 95,8 \\
\hline 2012 & 99,1 & 92,7 & 83,2 & 88,0 & 93,0 & 114,4 & 86,6 \\
\hline 2013 & 96,8 & 93,1 & 97,5 & 94,6 & 111,3 & 107,4 & 89,3 \\
\hline 2014 & 100,4 & 104,3 & 119,5 & 95,5 & 116,9 & 107,9 & 93,1 \\
\hline
\end{tabular}

Oznaczenia: P - Polska, WBR - Wielka Brytania, N - Niemcy, F - Francja, H - Hiszpania, PR - Portugalia, IR - Irlandia, FIN - Finlandia, CZ - Czechy, SŁE - Słowenia, SŁO - Słowacja, LI - Litwa, ŁO - Łotwa, W - Włochy.

Źródło: GUS (2015).

Tabela 2. Dynamika produkcji w budownictwie w krajach Unii Europejskiej w latach 2006-2014

\begin{tabular}{|c|c|c|c|c|c|c|c|}
\hline Lata & $\mathrm{G}$ & $\mathrm{E}$ & $\mathrm{M}$ & $\mathrm{L}$ & $\mathrm{B}$ & $\mathrm{BU}$ & $\mathrm{R}$ \\
\hline 1 & 2 & 3 & 4 & 5 & 6 & 7 & 8 \\
\hline 2006 & 103,7 & 126,9 & 104,7 & 102,3 & 103,7 & 124,1 & 115,5 \\
\hline 2007 & 114,3 & 113,6 & 108,7 & 102,8 & 102,0 & 128,2 & 133,1 \\
\hline 2008 & 107,8 & 86,8 & 107,5 & 98,9 & 100,7 & 112,0 & 126,7 \\
\hline 2009 & 82,5 & 70,2 & 103,4 & 100,1 & 96,6 & 85,4 & 85,0 \\
\hline 2010 & 70,8 & 91,4 & 101,7 & 100,2 & 98,6 & 85,1 & 86,6 \\
\hline 2011 & 58,7 & 127,3 & 104,5 & 101,1 & 105,3 & 87,4 & 102,9 \\
\hline 2012 & 66,6 & 116,7 & 101,7 & 96,9 & 99,1 & 99,3 & 101,4 \\
\hline 2013 & 91,8 & 99,9 & 101,9 & 95,7 & 97,2 & 96,3 & 99,4 \\
\hline 2014 & 115,5 & 97,4 & 101,2 & 103,2 & 99,8 & 101,7 & 93,3 \\
\hline & $\mathrm{CH}$ & $\mathrm{HL}$ & $\mathrm{SZ}$ & $\mathrm{WG}$ & $\mathrm{D}$ & $\mathrm{C}$ & $\mathrm{A}$ \\
\hline 2006 & 111,6 & 103,3 & 112,0 & 99,2 & 106,0 & 104,1 & 105,9 \\
\hline 2007 & 104,2 & 106,2 & 111,4 & 85,7 & 102,6 & 106,8 & 103,9 \\
\hline 2008 & 114,5 & 104,0 & 98,6 & 95,0 & 100,6 & 102,3 & 99,2 \\
\hline 2009 & 93,1 & 95,5 & 87,9 & 95,7 & 89,6 & 89,4 & 98,2 \\
\hline 2010 & 83,0 & 89,1 & 107,8 & 89,5 & 90,6 & 92,0 & 95,9 \\
\hline 2011 & 88,6 & 100,9 & 102,4 & 92,0 & 103,8 & 89,0 & 101,9 \\
\hline 2012 & 88,1 & 91,9 & 96,0 & 93,4 & 99,7 & 80,9 & 103,5 \\
\hline
\end{tabular}




\begin{tabular}{|c|c|c|c|c|c|c|c|}
\hline 1 & 2 & 3 & 4 & 5 & 6 & 7 & 8 \\
\hline 2013 & 94,7 & 95,2 & 96,6 & 108,4 & 103,2 & 76,3 & 100,4 \\
\hline 2014 & 92,7 & 103,2 & 112,5 & 113,6 & 103,5 & 76,9 & 98,2 \\
\hline
\end{tabular}

Oznaczenia: G - Grecja, E - Estonia, M - Malta, L - Luksemburg, B - Belgia, BU - Bułgaria, R - Rumunia, CH - Chorwacja, HL - Holandia, SZ - Szwecja, WG - Węgry, D - Dania, C - Cypr, A - Austria.

Źródło: GUS (2015).

\section{Analiza statystyczna danych}

Na rysunku 1 widać, że największą dynamikę produkcji w budownictwie w Polsce odnotowano w roku 2007 i wynosiła ona 116,5. Natomiast najniższą zaobserwowano w 2012 roku i miała wartość 93,7.

Rysunek 1. Wskaźniki dynamiki o podstawie zmiennej produkcji w budownictwie w Polsce w latach 2006-2014

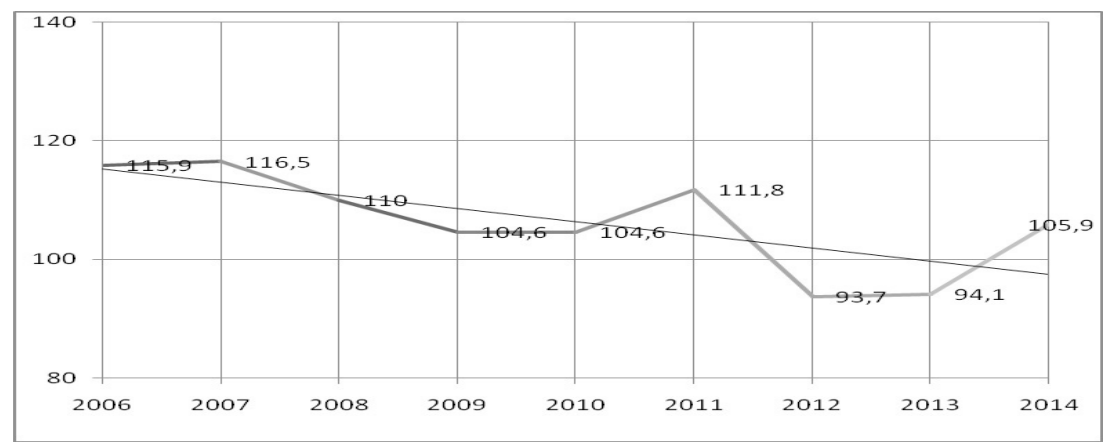

Źródło: opracowanie własne z wykorzystaniem tabel 1-2 i pakietu MS Excel.

Spadek w latach 2007-2012 wyniósł około 20 p.p. Zaznaczony na rysunku 1 trend liniowy ma charakter lekko spadkowy. Jak wynika z tabel 1-2, największą wartość wskaźnika dynamiki produkcji w budownictwie na poziomie 133,1 zanotowano w Rumunii w 2007 roku, zaś najniższą na Litwie w 2009 roku i wynosiła ona 51,7. Wskaźniki dynamiki wszystkich krajów Unii Europejskiej w latach 2006-2014 mieściły się w przedziale $[51,7 ; 133,1]$.

Największą średnią wartość wskaźnika dynamiki produkcji w budownictwie w Unii Europejskiej na poziomie 106 w latach 2006-2014 odnotowano w Polsce. 
Dalsze miejsca w kolejności zajmowały: Rumunia (105), Litwa (104), Malta (104), Finlandia (103), Szwecja (103), Estonia (103), Niemcy (102), Bułgaria (102) itd. W czterech krajach przeciętna wartość wskaźnika dynamiki była na poziomie 100, w pięciu na poziomie 99. Najniższa średnia wartość występowała w Irlandii i wynosiła 88. W stosunku do Irlandii średnia wartość wskaźników dynamiki w latach 20062014 w Polsce była o 18 p.p. większa. W innych krajach Unii Europejskiej średni poziom dynamiki był niższy od średniej dynamiki w Polsce w granicach 1-16 p.p. Na wysoką średnią wartość dynamiki w Polsce miały wpływ lata 2006-2011 oraz rok 2014, gdzie zanotowano poziom dynamiki powyżej 100.

Rysunek 2. Średnie wartości wskaźników dynamiki produkcji w budownictwie w krajach Unii Europejskiej w okresie 2006-2014 (średnie wartości zaokrąglono do liczb naturalnych)

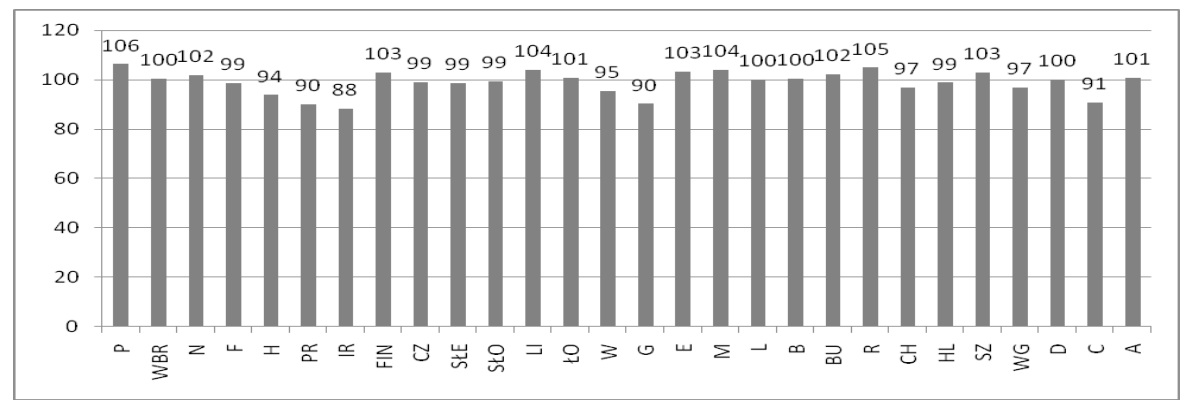

Źródło: opracowanie własne z wykorzystaniem tabel 1-2 i pakietu MS Excel.

Rysunek 3. Trend i realizacje średnich wartości wskaźników dynamiki produkcji w budownictwie w krajach Unii Europejskiej w latach 2006-2014

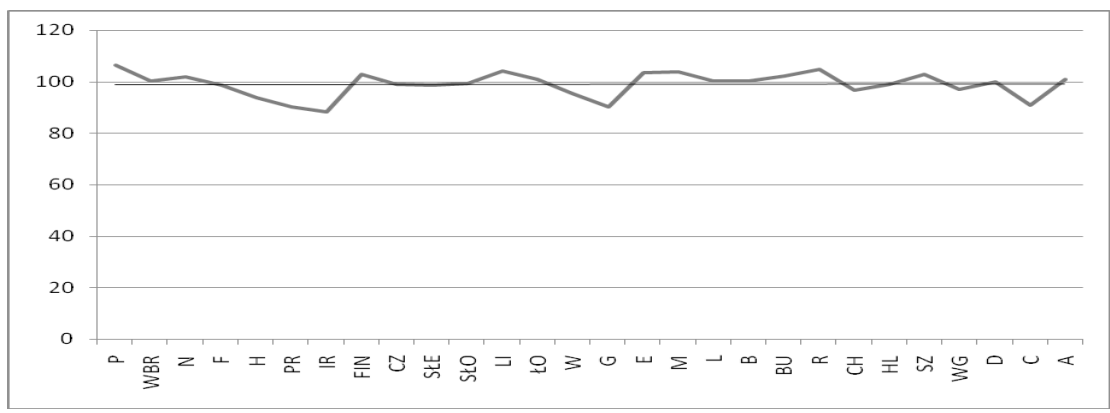

Źródło: opracowanie własne z wykorzystaniem tabel 1-2 i pakietu MS Excel. 
Jak widać na rysunku 3, trend liniowy dotyczący średnich wartości dynamiki w budownictwie w krajach Unii Europejskiej w okresie 2006-2014 był w przybliżeniu stały i wynosił około 100 .

Rysunek 4. Trend i realizacje przeciętnych stóp wzrostu wskaźników dynamiki produkcji w budownictwie w krajach Unii Europejskiej w latach 2006-2014 (wartości zaokrąglono do liczb naturalnych)

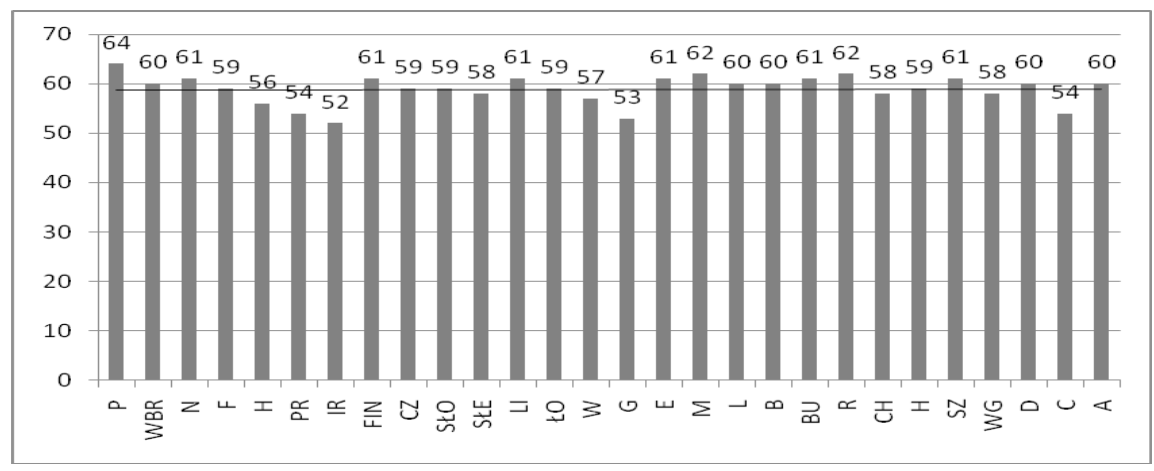

Źródło: opracowanie własne z wykorzystaniem tabel 1-2 i pakietu MS Excel.

Przeciętne stopy wzrostu ukazane na rysunku 4 obliczono jako pierwiastki dziewiątego stopnia z iloczynu wskaźników dynamiki podzielonych przez 100. Trend liniowy przeciętnych stóp wzrostu wskaźników dynamiki w krajach Unii Europejskiej w latach 2006-2014 był w przybliżeniu stały i wynosił około 59 . Największą przeciętną stopę wzrostu wskaźników dynamiki na poziomie 64 odnotowano w Polsce. Dalsze miejsca zajęły: Rumunia (62), Malta (62), Finlandia (61), Litwa (61), Szwecja (61), Estonia (61), Niemcy (61), Bułgaria (61) itd. Najniższą przeciętną stopę wzrostu równą 52 miała Irlandii. Ponadto analizując rysunki 2 i 4, widać, że rozkłady średnich wartości wskaźników dynamiki produkcji oraz przeciętnych stóp wzrostu wskaźników dynamiki produkcji krajów Unii Europejskiej w latach 2006-2014 są do siebie bardzo podobne. 
Rysunek 5. Wartości odchylenia standardowego obliczone dla dynamiki w budownictwie krajów Unii Europejskiej w latach 2006-2014

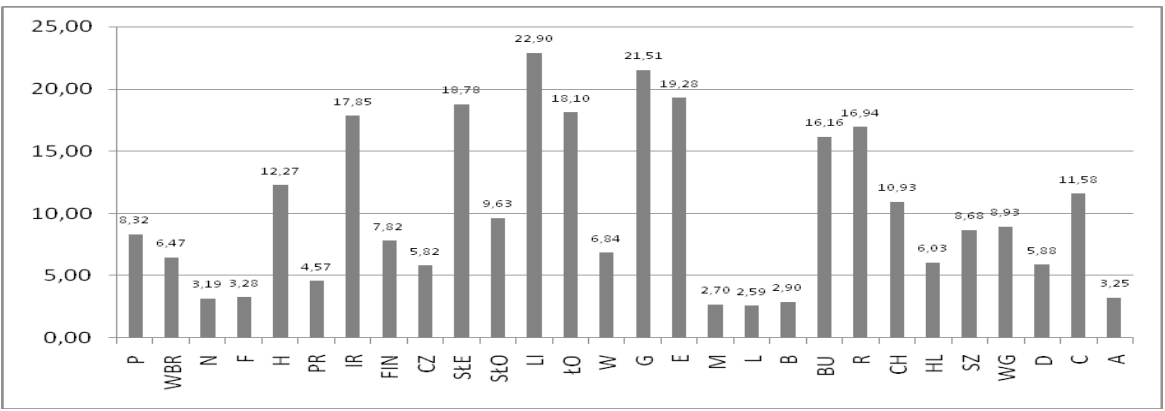

Źródło: opracowanie własne z wykorzystaniem tabel 1-2 i pakietu MS Excel.

Największy rozrzut od wartości średniej wskaźników dynamiki mierzony odchyleniem standardowym odnotowano w latach 2006-2014 na Litwie (22,90). Na drugiej pozycji uplasowała się Grecja $(21,51)$. Najniższe odchylenie standardowe występowało w Luksemburgu $(2,59)$. Odchylenie standardowe obliczone dla Polski wynosiło 8,32 i mieściło się w przybliżeniu w średnim stanie odchyleń standardowych. Po wykonaniu obliczeń za pomocą pakietu Statistica 5.0 ujemne wartości współczynników kurtozy otrzymano dla 21 państw. Dotyczyło to Polski $(-0,76)$, Niemiec $(-0,25)$, Francji $(-0,43)$, Portugalii $(-1,25)$, Irlandii $(-1,65)$, Czech $(-1,70)$, Słowenii $(-2,25)$, Słowacji $(-0,70)$, Włoch $(-0,97)$, Grecji $(-1,67)$, Estonii $(-0,73)$, Malty $(-0,49)$, Luksemburga $(-0,66)$, Belgii $(-0,63)$, Bułgarii $(-0,99)$, Rumunii $(-0,79)$, Chorwacji $(-0,86)$, Holandii $(-1,35)$, Szwecji $(-1,01)$, Cypru $(-1,52)$ i Austrii $(-0,96)$. Ujemne współczynniki kurtozy świadczą o tym, że wartości rozkładów ukazanych zmiennych są mniej skoncentrowane wokół wartości średniej, niż ma to miejsce w przypadku rozkładu normalnego (Hozer, 1998, s. 111-116). Dodatni współczynnik kurtozy występował w przypadku 7 państw: Wielkiej Brytanii $(0,21)$, Hiszpanii $(0,27)$, Finlandii $(0,42)$, Litwy $(3,08)$, Łotwy $(0,69)$, Węgier $(0,23)$ i Danii $(0,14)$. Dodatnie współczynniki kurtozy świadczą o tym, że wartości rozkładów są tutaj bardziej skoncentrowane wokół wartości średniej, niż ma to miejsce w przypadku rozkładu normalnego.

Podobnie po wykonaniu obliczeń za pomoca pakietu Statistica 5.0 otrzymano, że ujemny współczynnik skośności występował w przypadku 14 państw: Polski $(-0,48)$, Wielkiej Brytanii $(-0,75)$, Portugalii $(-0,10)$, Irlandii $(-0,08)$, Finlandii $(-0,83)$, Słowenii $(-0,02)$, Litwy $(-1,68)$, Lotwy $(-1,41)$, Grecji $(-0,22)$, Estonii 
$(-0,29)$, Luksemburga $(-0,59)$, Holandii $(-0,44)$, Szwecji $(-0,36)$ i Danii $(-1,23)$. Ujemne współczynniki skośności dotyczące rozkładów wyszczególnionych zmiennych świaczą o lewostronnej asymetrii tych rozkładów. Dodatni współczynnik skośności odnotowano również w przypadku 14 państw Unii Europejskiej: Niemiec $(1,04)$, Francji $(0,55)$, Hiszpanii $(0,70)$, Czech $(0,17)$, Słowenii $(0,70)$, Włoch $(0,34)$, Malty $(0,86)$, Belgii $(0,49)$, Bułgarii $(0,61)$, Rumunii $(0,61)$, Chorwacji $(0,67)$, Węgier $(0,93)$, Cypru $(0,11)$ i Austrii $(0,14)$. Silna asymetria występowała w przypadku rozkładu zmiennych: Litwa, Łotwa, Dania, Niemcy, zaś umiarkowana w przypadku rozkładu pozostałych zmiennych.

Tabela 3. Wartości współczynników korelacji wskaźników dynamiki budownictwa w Polsce i w wybranych krajach Unii Europejskiej w latach 2006-2014. Oznaczone współczynniki są istotne z prawdopodobieństwem $p<0,05$

\begin{tabular}{|l|c|c|c|c|c|c|c|c|c|c|c|}
\hline & $\mathrm{P}$ & $\mathrm{N}$ & $\mathrm{PR}$ & $\mathrm{CZ}$ & $\mathrm{S} Ł O$ & $\mathrm{~W}$ & $\mathrm{M}$ & $\mathrm{L}$ & $\mathrm{B}$ & $\mathrm{HL}$ & $\mathrm{C}$ \\
\hline $\mathrm{P}$ & 1,0 & $\mathbf{0 , 6 8}$ & $\mathbf{0 , 8 4}$ & $\mathbf{0 , 7 8}$ & $\mathbf{0 , 7 6}$ & $\mathbf{0 , 8 9}$ & $\mathbf{0 , 7 3}$ & $\mathbf{0 , 8 2}$ & $\mathbf{0 , 7 3}$ & $\mathbf{0 , 7 5}$ & $\mathbf{0 , 8 2}$ \\
\hline $\mathrm{N}$ & $\mathbf{0 , 6 8}$ & 1,0 & 0,24 & 0,48 & 0,45 & 0,51 & 0,27 & 0,62 & $\mathbf{0 , 8 9}$ & 0,57 & 0,29 \\
\hline PR & $\mathbf{0 , 8 4}$ & 0,24 & 1,0 & $\mathbf{0 , 8 2}$ & $\mathbf{0 , 7 7}$ & $\mathbf{0 , 8 2}$ & $\mathbf{0 , 7 7}$ & $\mathbf{0 , 6 8}$ & $\mathbf{0 , 6 8}$ & $\mathbf{0 , 7 4}$ & $\mathbf{0 , 8 3}$ \\
\hline CZ & $\mathbf{0 , 7 8}$ & 0,48 & $\mathbf{0 , 8 2}$ & 1,0 & 0,65 & $\mathbf{0 , 6 9}$ & 0,57 & $\mathbf{0 , 7 9}$ & 0,43 & $\mathbf{0 , 8 7}$ & 0,57 \\
\hline SŁÓ & $\mathbf{0 , 7 6}$ & 0,45 & $\mathbf{0 , 7 7}$ & 0,65 & 1,0 & $\mathbf{0 , 8 6}$ & $\mathbf{0 , 7 0}$ & 0,41 & 0,62 & $\mathbf{0 , 7 2}$ & $\mathbf{0 , 7 9}$ \\
\hline W & $\mathbf{0 , 8 9}$ & 0,51 & $\mathbf{0 , 8 2}$ & $\mathbf{0 , 6 9}$ & $\mathbf{0 , 8 6}$ & 1,0 & $\mathbf{0 , 7 6}$ & 0,65 & 0,66 & $\mathbf{0 , 6 8}$ & $\mathbf{0 , 8 6}$ \\
\hline M & $\mathbf{0 , 7 3}$ & 0,27 & $\mathbf{0 , 7 7}$ & 0,57 & $\mathbf{0 , 7 0}$ & $\mathbf{0 , 7 6}$ & 1,0 & 0,33 & 0,50 & $\mathbf{0 , 7 1}$ & $\mathbf{0 , 8 6}$ \\
\hline L & $\mathbf{0 , 8 2}$ & 0,62 & $\mathbf{0 , 6 8}$ & $\mathbf{0 , 7 9}$ & 0,41 & 0,65 & 0,33 & 1,0 & 0,54 & 0,61 & 0,46 \\
\hline B & $\mathbf{0 , 7 3}$ & $\mathbf{0 , 8 9}$ & $\mathbf{0 , 6 8}$ & 0,43 & 0,62 & 0,66 & 0,50 & 0,54 & 1,0 & 0,62 & 0,50 \\
\hline HL & $\mathbf{0 , 7 5}$ & 0,57 & $\mathbf{0 , 7 4}$ & $\mathbf{0 , 8 7}$ & $\mathbf{0 , 7 2}$ & $\mathbf{0 , 6 8}$ & $\mathbf{0 , 7 1}$ & 0,61 & 0,62 & 1,0 & 0,51 \\
\hline C & $\mathbf{0 , 8 2}$ & 0,29 & $\mathbf{0 , 8 3}$ & 0,57 & $\mathbf{0 , 7 9}$ & $\mathbf{0 , 8 6}$ & $\mathbf{0 , 8 6}$ & 0,46 & 0,50 & 0,51 & 1,0 \\
\hline
\end{tabular}

Uwaga: Istotne współczynniki korelacji oznaczono boldem i kursywą. Źródło: opracowanie własne z wykorzystaniem tabel 1-2 i pakietu Statistica 5.0.

W tabeli 3 podano tylko te kraje, które miały z dynamiką budownictwa w Polsce istotne współczynniki korelacji (Kowgier, 2011, s. 115-116). W przypadku pozostałych 18 państw Unii Europejskiej nie występowały istotne korelacje z dynamiką budownictwa w Polsce, dlatego je pominięto. Ponadto ukazano również współczynniki 
korelacji, które występowały między dynamiką budownictwa w wyszczególnionych 10 krajach Unii Europejskiej. Na uwagę zasługuje fakt, że wszystkie istotne współczynniki korelacyjne między Polską a wymienionymi krajami, jak również między podanymi krajami przyjmowały wysokie wartości dodatnie. Świadczy to o tym, że wzrost dynamiki budownictwa w jednym kraju zawsze powodował wzrost dynamiki budownictwa w innym kraju. Między dynamiką budownictwa w Polsce (przy założeniu, że zmienna $P$ jest zmienną objaśnianą) a dynamiką w poszczególnych 10 krajach występowała zależność liniowa $z$ istotnym parametrem i wyrazem wolnym tylko w jednym przypadku:

$$
P=\underset{(0,16)}{0,59 \cdot C}+\underset{(14,27)}{52,92}, R^{2}=0,67
$$

W nawiasach zwykłych podano standardowe błędy szacunku parametru stojącego przy zmiennej Cypr oraz wyrazu wolnego.

Aby zbadać istotność statystyczną parametrów strukturalnych występujących w modelu ekonometrycznym, należy sprawdzić, czy parametry te istotnie różnią się od zera. Do tego celu wykorzystujemy test istotności $t$-Studenta. Weryfikujemy hipotezę zerową $H_{0}:\left|\alpha_{i}\right|=0$ przy hipotezie alternatywnej $H_{1}:\left|\alpha_{i}\right| \neq 0 \quad(i=0,1,2, \ldots k)$. Sprawdzianem testu istotności jest statystyka $t$-Studenta liczona według wzoru $\left|t_{\hat{\alpha}_{i}}\right|=\frac{\left|\hat{\alpha}_{i}\right|}{D\left(\hat{\alpha}_{i}\right)}$, gdzie $\hat{\alpha}_{i}$ - ocena $i$ - tego parametru strukturalnego, $D\left(\hat{\alpha}_{i}\right)-$ standardowy błąd szacunku parametru strukturalnego $\hat{\alpha}_{i}$. W przypadku modelu (1) otrzymano:

$$
\left|t_{\hat{C}}\right|=\frac{0,59}{0,16}=3,68>t_{0,05 ; 7}=2,36,|t|=\frac{52,92}{14,27}=3,7>2,36,
$$

gdzie $t_{0,05 ; 7}=2,36$ - wartość krytyczna statystyki $t$-Studenta obliczona dla poziomu istotności 0,05 oraz 7 stopni swobody. Uzyskane powyżej nierówności: 3,68 >2,36; 3,7 > 2,36 świadczą o tym, że hipotezę $H_{0}$ na poziomie istotności $0,05 \mathrm{w}$ obu przypadkach należy odrzucić na korzyść hipotezy $H_{1}$. Zatem parametry występujące w modelu (1) są istotne statystycznie. Stopień dopasowania modelu do danych rzeczywistych wynosi $67 \%$. W pozostałych 9 przypadkach (rozpatrując modele z jedną zmienną objaśniającą) otrzymano istotne statystycznie parametry stojące przy zmiennych objaśniających oraz nieistotne statystycznie wyrazy wolne. 
Analogicznie

$$
\begin{aligned}
& P=\underset{(0,39)}{1,83} \cdot \underset{(0,08)}{0,40} \cdot \underset{(36,62)}{1113,3}, R^{2}=0,92 \\
& \left|t_{\hat{L}}\right|=\frac{1,83}{0,39}=4,69>t_{0,05 ; 6}=2,45 ;\left|t_{\hat{C}}\right|=\frac{0,4}{0,08}=5,0>t_{0,05 ; 6}=2,45|t|=\frac{113,3}{36,62}=3,09>2,45
\end{aligned}
$$

Wobec powyższego widać, że 4,69>2,45; $5>2,45 ; 3,09>2,45$. Zatem wszystkie zmienne użyte w równaniu regresji (2) są potrzebne przy prognozowaniu szacunkowej wartości zmiennej $P$. Stopień dopasowania modelu do danych rzeczywistych wynosi $92 \%$.

Względne błędy oszacowań parametrów przyjmują wartości:

$$
\frac{0,08}{0,4} \cdot 100 \%=20 \%<50 \% ; \frac{0,39}{1,83} \cdot 100 \%=21,31 \%<50 \%, \frac{36,62}{113,3} \cdot 100 \%=32,32 \%<50 \% \text {. }
$$

Zatem model jest liniowy i ma własności prognostyczne, ponieważ wartość statystyki $F$-Snedecora obliczona numerycznie za pomocą funkcji Reglinp w Excelu spełnia relację: $F=38,6>F_{0,05 ; 2 ; 6}=5,14$, gdzie $F_{0,05 ; 2,6}=5,14$ jest wartością krytyczną testu $F$-Snedecora przy poziomie istotności 0,05 ; dwóch zmiennych i 6 stopniach swobody.

Stosując metodę Hellwiga doboru zmiennych do modelu, gdzie zmienną objaśnianą jest $P$, a zmiennymi „objaśniającymi” $L, C, N$, otrzymano po wykorzystaniu wzoru na pojemności indywidualne, tabeli 3 i siedmiu kombinacji:

$$
K_{1}=\{L\}, K_{2}=\{C\} ; K_{3}=\{N\} ; K_{4}=\{L, C\} ; K_{5}=\{L, N\} ; K_{6}=\{C, N\} ; K_{7}=\{L, C, N\},
$$

gdzie $L=X_{1 i}, C=X_{2 i}, N=X_{3 i}, P=Y_{i}$.

$$
h_{i j}=\frac{r_{j}^{2}}{1+\sum_{\substack{i=1 \\ i \neq j}}^{k}\left|r_{i j}\right|}
$$

$h_{11}=0,672 ; h_{22}=0,672 ; h_{33}=0,384 ; h_{41}=0,4148 ; h_{42}=0,4148 ; h_{51}=0,2317 ; h_{52}=0,5209 ;$

$h_{62}=0,4603 ; h_{63}=0,2633 ; h_{71}=0,3518 ; h_{72}=0,3231 ; h_{73}=0,2197$.

Pojemności integralne przyjęły następujące wartości:

$$
\begin{aligned}
& H_{1}=0,672 ; H_{2}=0,672 ; H_{3}=0,384 ; H_{4}=h_{41}+h_{42}=0,8296 ; \\
& H_{5}=h_{51}+h_{53}=0,7236 ; H_{6}=h_{62}+h_{63}=0,7236 ; H_{7}=h_{71}+h_{72}+h_{73}=0,8946=H_{o p t}
\end{aligned}
$$


Zatem wszystkie zmienne $L, C$ i $N$ należy wziąć pod uwagę, tworząc model liniowy opisujący zmienną $P$. Wykorzystując funkcję statystyczną Reglinp, w MS Excel otrzymano:

$$
P=\underset{(0,32)}{1,28} L+\underset{(0,06)}{0,40} C \underset{(0,25)}{0,7} \cdot N-\underset{(36,62)}{113,3}, R^{2}=0,97
$$

Ponieważ względne błędy oszacowań parametrów stojących przy zmiennych $L, C, N$ i wyrazie wolnym są mniejsze od $50 \%$, więc otrzymany model jest liniowy. Stopień jego dopasowania do danych rzeczywistych wynosi 97\%. Statystyki empiryczne testu $t$-Studenta dla poszczególnych parametrów przyjmują wartości odpowiednio:

$$
\left|t_{\hat{L}}\right|=\frac{1,28}{0,32}=4,0>t_{0,05 ; 5}=2,57 ;\left|t_{\hat{C}}\right|=\frac{0,4}{0,06}=6,67>t_{0,05 ; 5}=2,57 ;\left|t_{\hat{N}}\right|=\frac{0,7}{0,25}=2,8>t_{0,05 ; 5}=2,57 ;
$$

$|t|=\frac{113,3}{36,62}=3,09>2,57 ; t_{0,05 ; 5}=2,57-$ wartość krytyczna statystyki $t$-Studenta obliczona dla poziomu istotności 0,05 oraz 5 stopni swobody. Wobec powyższego widać, że $4,0>2,57 ; 6,67>2,57 ; 2,8>2,57 ; 3,09>2,57$. Zatem wszystkie zmienne użyte w równaniu regresji (4) są potrzebne przy prognozowaniu szacunkowej wartości zmiennej $P$. Model (4) ma własności prognostyczne, ponieważ

$$
F=59,44>F_{0,05 ; 3 ; 5}=5,41,
$$

czyli otrzymane równanie regresji (4) jest użyteczne przy prognozowaniu szacunkowej wartości zmiennej $P$ w następnych latach po 2014 roku. Po wykonaniu stosownych obliczeń zauważono również, że nie występują modele liniowe o odpowiednio: 4, 5, 6, 7 istotnych statystycznie współczynnikach stojących przy zmiennych, które mają istotne współczynniki korelacji ze zmienną $P$ traktowaną jako zmienna objaśniana w tych modelach. Poniżej podano przykłady takich modeli:

$$
P=\underset{(0,48)}{1,2} \cdot \underset{(0,07)}{0,39} \cdot \underset{(0,27)}{0,71 \cdot} N \underset{(0,2)}{0,05} \cdot C Z \underset{(31,0)}{127,84}
$$

błąd względny wyznaczenia parametru stojącego przy zmiennej $C Z$ wynosił $400 \%$,

$$
P=\underset{(0,33)}{1,41 \cdot} L+\underset{(0,13)}{0,23} C \underset{(0,26)}{0,58} N \underset{(0,44)}{0,57 \cdot} M+\underset{(0,11)}{0,08} \cdot S t O-\underset{(47,57)}{182,92}
$$


błąd względny wyznaczenia parametru stojących przy zmiennej $S Ł O$ był powyżej $100 \%$,

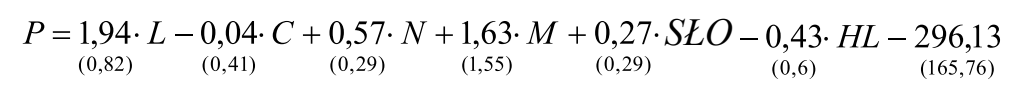

błędy względne wyznaczenia parametrów stojących przy zmiennych $C, S Ł O, H L$ były powyżej $100 \%$,

$$
P=\underset{(1,21)}{1,77 \cdot} L \underset{(0,99)}{0,25} C+\underset{(0,51)}{0,45} N+\underset{(3,88)}{0,27} \cdot M+\underset{(0,61)}{0,10} \cdot S t O \underset{(1,19)}{0,16} \cdot H L \underset{(0,87)}{0,30} \cdot C Z-\underset{(383,5)}{188,78}
$$

prawie wszystkie względne błędy były tu powyżej 100\%. Otrzymano także modele o istotnych statystycznie współczynnikach stojących przy zmiennych, które miały nieistotne statystycznie współczynniki korelacji ze zmienną objaśnianą $P$. Oto jeden z nich:

$$
P=\underset{(0,21)}{1,51 \cdot} \underset{(0,1)}{0,41 \cdot} H-\underset{(18,98)}{5,21}, R^{2}=0,89
$$

W powyższym modelu nieistotny statystycznie jest wyraz wolny. Ze zmienną Hiszpania Polska miała nieistotny współczynnik korelacji równy -0,11.

\section{Podsumowanie}

Dokonana analiza dotycząca porównania dynamiki produkcji w budownictwie w Polsce w latach 2006-2014 z dynamiką produkcji w budownictwie w krajach Unii Europejskiej skłania do pewnego optymizmu. Zauważona wysoka dynamika w Polsce wiązała się i w dalszym ciągu wiąże z dużymi potrzebami związanymi z szeroko pojętym budownictwem. W badanym okresie Polska otrzymała też dość znaczne środki z Unii Europejskiej na cele szeroko pojętego budownictwa. Średnia wartość wskaźnika dynamiki na poziomie 106 oraz średnia wartość stopy wzrostu na poziomie 64 w Polsce w okresie 2006-2014 była największa w Unii Europejskiej. Stwierdzono również wystąpienie istotnych statystycznie korelacji dynamiki w Polsce z dynamiką 9 krajów Unii Europejskiej. Traktując dynamikę w Polsce jako zmienną objaśnianą, zaś dynamiki w krajach Unii Europejskiej, z którymi Polska miała istotne statystycznie korelacje, jako zmienne „objaśniające”, otrzymano jeden modeli liniowy z jedną zmienną „objaśniającą” Cypr, jeden model liniowy z dwiema zmiennymi „objaśniającymi”: Luksemburg i Cypr oraz jeden model liniowy z trzema zmiennymi „objaśniającymi”: Luksemburg, Cypr i Niemcy. Nie występowały modele liniowe o 4, 5, 6, 7 istotnych współczynnikach 
stojących przy zmiennych, które miały istotne współczynniki korelacji ze zmienną Polska. Rozkłady zmiennych charakteryzujących dynamikę produkcji w budownictwie krajów Unii Europejskiej miały najczęściej umiarkowany stopień asymetrii, poza czterema przypadkami: Litwą, Łotwą, Danią i Niemcami. Średnia wartość wskaźników dynamiki wszystkich krajów Unii Europejskiej w latach 2006-2014 była w przybliżeniu stała i wynosiła około 100. Podobnie średnia wartości przeciętnych stóp wzrostu wszystkich krajów Unii była w przybliżeniu stała i miała wartość około 59. W przypadku aż 21 państw Unii Europejskiej zaobserwowano ujemne oceny wskaźników kurtozy.

\title{
Literatura
}

Bąk, I., Markowicz, I., Mojsiewicz, M., Wawrzyniak, K. (2002). Statystyka opisowa. Warszawa: WNT.

Begg, D., Fischer, S., Dornbusch, R. (1997). Makroekonomia. Warszawa: PWE.

GUS (2015). Rocznik statystyczny. Warszawa.

Hozer J. (red.). (1998). Statystyka, Szczecin: Ekostat.

Kowgier, H. (2011). Elementy rachunku prawdopodobieństwa i statystyki na przykładach z ekonomii. Warszawa: WNT.

\section{COMPARISON OF PRODUCTION DYNAMICS IN THE BUILDING INDUSTRY IN POLAND WITH THE PRODUCTION DYNAMICS IN THE BUILDING INDUSTRY IN EUROPEAN UNION COUNTRIES FOR THE YEARS 2006-2014}

\begin{abstract}
In the article has been compared dynamics of production in the building industry in Poland with the dynamics of production in the building industry of the EU during the period 2006-2014. Used statistical analysis regarding the correlation, regression and selected descriptive statistics. Appropriate conclusions finish work.
\end{abstract}

Translated by Henryk Kowgier

Keywords: statistical analysis, dynamics of production in building industry

JEL Code: O1 
